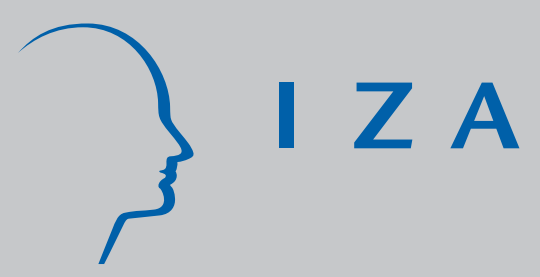

IZA DP No. 3843

Rank, Income and Income Inequality in Urban China

Björn Gustafsson

Ding Sai

November 2008 


\title{
Rank, Income and Income Inequality in Urban China
}

\author{
Björn Gustafsson \\ University of Gothenburg \\ and IZA \\ Ding Sai \\ Chinese Academy of Social Sciences
}

Discussion Paper No. 3843

November 2008

\author{
IZA \\ P.O. Box 7240 \\ 53072 Bonn \\ Germany \\ Phone: +49-228-3894-0 \\ Fax: +49-228-3894-180 \\ E-mail: iza@iza.org
}

\begin{abstract}
Any opinions expressed here are those of the author(s) and not those of IZA. Research published in this series may include views on policy, but the institute itself takes no institutional policy positions.

The Institute for the Study of Labor (IZA) in Bonn is a local and virtual international research center and a place of communication between science, politics and business. IZA is an independent nonprofit organization supported by Deutsche Post World Net. The center is associated with the University of Bonn and offers a stimulating research environment through its international network, workshops and conferences, data service, project support, research visits and doctoral program. IZA engages in (i) original and internationally competitive research in all fields of labor economics, (ii) development of policy concepts, and (iii) dissemination of research results and concepts to the interested public.
\end{abstract}

IZA Discussion Papers often represent preliminary work and are circulated to encourage discussion. Citation of such a paper should account for its provisional character. A revised version may be available directly from the author. 
IZA Discussion Paper No. 3843

November 2008

\section{ABSTRACT}

\section{Rank, Income and Income Inequality in Urban China ${ }^{*}$}

While some workers in China attain senior professional level and senior cadre level status (Chuzhang and above), others attain middle rank including middle rank of professional and cadre (Kezhang). This aspect of the Chinese labor force has attracted surprisingly little attention in the literature, a fact which this paper aims to rectify. We define various segments of the urban population in work-active ages and use data from the Chinese Income Project (CHIP) covering eastern, central and western China for 1995 and 2002. For 2002, persons of high rank make up 3 percent and persons of middle rank make up 14 percent of persons in work-active ages. Factors that affect a person's likelihood of having high or middle rank are investigated by estimating a multinomial probit model. We find that education, age and gender strongly affect the probability of being employed as a worker of high rank. There is relatively little income inequality among workers of high rank as well as among workers of middle rank. Mean income and household wealth per capita of highly-ranked workers developed more favorably than for other segments of the population studied, and personal income is more polarized by segment in 2002 than in 1995. Workers of high rank, and to a lesser degree, workers of middle rank, are among the winners in economic terms while the increasingly large category of non-workers are the losers. Rates of return to education have increased but income function analysis indicates that this provides only a partial explanation for the increased favorable income situation for workers of high and middle ranks.

JEL Classification: J21, J31, J41, P31

Keywords: China, rank, income, income inequality

Corresponding author:

Björn Gustafsson

Department of Social Work

University of Gothenburg

P.O. Box 720

SE 40530 Göteborg

Sweden

Email: Bjorn.Gustafsson@socwork.gu.se

\footnotetext{
* A previous version of the paper was presented at the 6th International Conference on the Chinese Economy, "Is China's Development Sustainable?", CERDI-IDREC, University of Auvergne, France, Clermont-Ferrand, October 18-19, 2007. We wish to acknowledge economic support from the Swedish Development agency (SIDA) and the Ford Foundation for collecting the data and for providing a scholarship for Ding Sai from the Swedish School of Asia Pacific Studies (SSAAPS) for a research period at University of Gothenburg where this work was done.
} 


\section{Introduction}

In the 1950s when China adopted a Soviet type of economic system, labor was centrally allocated within the cities. Workers typically had lifelong relations with the work unit where they originally started after having finished school. Wages were paid according to centrally determined wage scales in a system where workers were also compensated with in-kind payments, heavily subsidized housing, access to social services and social insurance benefits. At any given work unit, workers were categorized by rank in a system (Zhiwu Zhicheng Xilie) that perhaps most easily can be understood by likening it to how armed forces are organized. That is, there are various hierarchical levels that are based on occupation but also to some extent on personal characteristics. Many responsibilities signify a position of high rank. The procedures for obtaining a higher rank were well-known, and therefore it was (and still is) possible for the individual to plan a career. More highly-ranked workers received better remuneration than workers ranked lower. The highest-ranked workers were the economic elite.

Since the 1980s, urban China has undergone large changes in most aspects of economic life. Notably, new forms of ownership have multiplied. Thus men and women who work in foreign-invested companies, are self-employed, or work in private or collective enterprises, are not covered by the ranking system and new economic elites have emerged. Just as important as the rank system covering fewer persons is that employment rates have fallen from their earlier very high levels. This is mainly due to structural changes during the second part of the 1990s when work units laid off workers on a large scale, resulting in a shrinking labor force and increased unemployment. Nonetheless, the system of rank has survived and continues to cover many workers. What has happened to the former economic elite? Has the economic situation of high-ranking workers deteriorated? Or have high-ranking workers retained their numbers and managed to "surf on the waves of change"? Given that many consider rank an important aspect of the job, and that it ensures higher remuneration and well-being, the answers to these questions are clearly of interest.

The issue of how elites have fared during the transition from planned to market economy has attracted much interest in the sociological literature. As early as 1989 Victor Nee published a paper proposing a general theory for societies in transition (Nee, 1989). It was based on a study of income for cadre and other households in rural China collected in 1984. According to Nee, the introduction and expansion of market institutions give rise to multiple bases of power, 
privilege, and change in the structure of opportunity and incentive. Further, human capital provides more income benefits, while the influence of political capital vanishes.

Claiming to be a general theory, the original paper of Nee has stimulated theoretical developments such as Walder (2003) as well as many studies of income among elites in countries in transition. Several studies have addressed the issue of remuneration of elites in urban China during transition, see for example Walder (1995), Bian and Logan (1996) and more recently Bian and Zhang (2004) as well as Chao and Nee (2005). While these studies do not explicitly focus on the workers' rank, studies that have used some thousand life histories collected in twenty cities in 1993 and 1994 do (see Zhou, Tuma and Moen 1997, Zhou and Ho 1999, Walder, Li and Treiman 2000, Zhou 2000 and, building on most of them, Zhou 2004). These studies analyse entry into elite occupations, promotion in the rank system as well as the role of rank in income determination. They also investigate to what extent various cohorts of workers have fared differently.

Our aims for this paper are twofold. First we wish to better understand what makes some people more likely than others to possess high and middle-high rank, respectively. To what extent do education, age and gender play a role and are there intergenerational influences? Is rank status influenced by people's forced migration experience during the Cultural Revolution or from experiencing rural to urban migration? The second aim is to describe and analyse the development of personal income among people of high, middle and low ranks. In particular we are interested in whether or not the income advantage of being a high- or middle-ranked worker has changed, and whether a person's rank has an independent effect on personal money income when personal characteristics such as education, age and location are considered. This means that our aims resemble those of the sociological studies that have analyzed life histories to understand elite recruitment and how elite status affects income. Like these studies, we use data covering large parts of urban China. However, this study differs in several aspects from the sociological studies referred to above. First, we define labor market segments differently. Second, we apply another modeling strategy when analyzing the process of having elite status and to some extent also when analyzing income determination. Third, and perhaps most importantly, we study a more recent period; in addition to analyzing data for 1995 we also use data from 2002. Between these two years, State Owned Enterprises were put under heavy market pressure due to enterprise reform. This led to restructuring and layoffs and reform 
resulted in many workers in SOEs no longer being covered by the ranking system. ${ }^{2}$ At the onset it can also be useful to make clear that while this paper attempts to provide new knowledge on the fate of the old economic elite, it does not address issues of recruitment and income situation of the new economic elite made up of entrepreneurs, private owners and top- and middle-management in the sectors not covered by the rank system.

We find that education and age positively affect the probability of achieving the rank of high and middle status. We also find that being male strongly affects the probability of having a high rank. The probability for reaching the rank of high or middle increases if the worker has migrated from rural China and is a member of CPC, while the opposite is true for a worker who was sent to the countryside during the Cultural Revolution.

Turning to the second research question we find that personal income within the categories workers of high rank and workers of middle rank is relatively equally distributed and has developed more favorably than for other segments. The workers of high rank and to a lesser degree those of middle rank, are among the winners in China's transition towards a market economy, as their personal income, disposable household per capita income, household wealth and housing per capita increased more rapidly than for most other categories. In contrast, the losers are made up of a larger and larger group of non-workers. In 2002, personal income in urban China is more polarized by labour market segment than in 1995.

The rest of the paper is laid out as follows: In the next section we discuss the context with emphasis on how workers are ranked, while the database for the study is presented in Section 3. In Section 4 we define the categories under study, report their relative numbers and provide basic information on their characteristics. The analysis of what affects people's labor market segment is addressed in Section 5. In Section 6, income among people belonging to different segments is analyzed. The paper ends with a concluding section.

\footnotetext{
${ }^{2}$ There are also differences in how data was collected. The data the sociologists analyzed was collected at one point in time using many retrospective questions, while we use repeated cross sections. Our data covers 89 cities, while the data analyzed by the sociologists is from 20 cities and oversamples larger cities. We analyze yearly income, while the sociologists had access to monthly income.
} 


\section{Context}

The ranking system (Zhiwu Zhicheng Xilie) was taken from the Soviet Union to China for its national government departments, institutions and state-owned enterprises. A rank was (and still is) important for the level of wages, but in many cases is even more important for obtaining subsidized housing and for being entitled to welfare benefits such as health care at a low or no cost. A person's rank was and is also central for a career and for pension size when retiring from work.

The rank system establishes a hierarchy with many levels. ${ }^{3}$ For example, in the governmental sphere there are fifteen grades with the Prime Minister having the highest, vice ministers belong to the fourth and fifth grades, and county leaders grades seven to ten. In short: The majority of workers have no rank, some are of middle rank and only a few have a high rank. The proportion of workers being high or middle rank varied across work units.

Looking more closely one can find that the system consists of two parts. One is applied only for workers with cadre status and is called the post-appointment system (Zhiwu Xilie). The other is for professional and technical workers and is called the professional, technical title system (Zhicheng Xilie). In our view, remuneration, housing and health care benefits are rather similar and these two parts can be considered as one system for our research questions. ${ }^{4}$ This view is supported by the fact that a worker can have a rank in both sub-systems. ${ }^{5}$ Increasingly, there is a tendency for larger numbers of persons to have a rank not only in the professional title system but also in the post appointment system. Being ranked in two systems rather than one can be advantageous for the worker as he or she can receive higher wages, for example.

Different channels for gaining the status of state cadre have existed. During the planning epoch if persons graduated from a college or another form of higher education they were certain of being allocated a job by the government and attaining state cadre status. More recently the labour market perform this function, but with uncertainty for the individual. A second channel

\footnotetext{
${ }^{3}$ See Tang (2006), Luo and Lu (2005) as well as Zhagn and Yuan (2007).

${ }^{4}$ For another view see Walder, Li and Treiman (2000). In our data for 2002 average personal income for low-rank cadre is only 5 percent higher than for low-rank professional. The corresponding differences were among middle rank 6 percent and among high rank only 2 percent.

${ }^{5}$ For example if a person performs professional work and is promoted to the head of an institution, he or she might not only belong to Zhicheng Xilie but also to Zhiwu Xilie. It means that a person could be Chuzhang (senior cadre level) and have a high professional title. Similarly, if a person is an official and performs professional work, he or she could be in both systems.
} 
applies to people with lower levels of education. In time, and with a good work record, they could be promoted to state cadre status. Thus rank position depended not only on education, but also on perceived qualifications. A third channel applied to army cadres who left their duties and thereby were placed into a rank position.

If persons wish to increase their rank in the technical title system or the post appointment system, they must qualify. Each of the systems has its own standards for improving a worker's rank level. To give an example, if a low-rank person wishes to become middle rank, or a middle-rank person wishes to be promoted to high rank, the person must have the required work experience.

During the reform era the ranking system has changed. With the development of the State-owned Enterprises’ reform, the ranking system was phased out from the state owned enterprises, a process that had not fully ended when our data for 2002 was collected. However, this dramatic change has not meant a dismantling of the ranking system. Instead, a new process of qualification examinations has been created. Outsiders might perceive this as a reinstatement of the imperial examination system though in a modernized form, while many insiders are sympathetic as it can make the process of improving one’s rank less arbitrary.

There are several large categories of China's Zhicheng (professional, technical title system) examinations for people working in fields such as economics, accounting, engineering, law and judiciary, health and sanitation, IT, foreign languages, etc. Each of these categories has its own specific examinations. For example, there are nine kinds of examinations for accountants. The examinations take place once a year on a given date all over China. They are composed of a written part, which is identical for all applications, and in several cases also an oral part. To take part in the examination an applicant must receive approval from his or her superior and must register. If the examination is passed, the worker receives the relevant professional title.

\section{Data}

This study uses two large surveys of urban residents conducted in the spring of 1996 and 2003, respectively, for the reference years 1995 and 2002. The survey instruments were designed by the researchers of the China Income Distribution Project (CHIP), a group of researchers at the Institute of Economics, Chinese Academy of Social Sciences, Beijing and scholars from other 
countries. The project was assisted by the Team of Urban Surveys at the National Bureau of Statistics (NBS) that conducted the fieldwork.

The survey was obtained from larger samples used by NBS to produce official statistics for China. Much of the policy making in China is directed to specific regions; the eastern, central and western regions. Economic reform was first introduced in the eastern regions, while more recent policymaking has been directed to the western region, which has lagged behind the others in development. At a first stage of selecting the sample, the municipality of Beijing and the provinces of Liaoning, Jiangsu and Guangdong were chosen to represent the eastern region, the provinces Shanxi, Anhui, Henan and Hubei to represent the central region, and the municipality of Chongqing and the provinces of Gansu, Sichuan and Yunnan to represent the western region.

From these provinces a sample of 6934 households living in 69 cities was obtained for 1995 and a sample of 6835 households living in 70 cities for 2002. The sample frame for the urban sample is based on registers of people possessing a hukou. Thus it does not cover rural migrants living in urban China. ${ }^{6}$ Comparability across the two surveys is high in many respects, though the information on personal background is richer in 2002. While several authors have used the survey to study earnings inequality and earnings determination among urban workers, they have not focused on workers' rank, its determinants as well as income, as we do here. ${ }^{7}$

\section{Categories}

We study people aged 16 to 55 (female) and 16 to 60 (male), that is, the upper age limit is set at the age when most people have retired. Based on survey questions on occupation during most of the year, we define five labour-market segment categories. The residual category consists of non-workers (for example students, homemakers, early-retired, and unemployed). Some people in the residual category can have been employed some, but not all of, the year investigated. Within the category workers, some make their livelihood outside the sectors covered by the

\footnotetext{
${ }^{6}$ For further information on the data see Li et al (2008).

${ }^{7}$ Earlier studies using the 1995 survey include Gustafsson and Li (2001) and Knight and Song (2003), both in connection with the survey from 1988. Appleton et al (2005) and Knight and Song (2008) are examples of studies which have estimated earnings functions using the 1995 and 2002 surveys. Some authors have used the surveys to focus on gender-related issues, which include the following studies using the 1988 and 1995 surveys, Gustafsson and Li (2000), Bishop et all. (2005) and Démuger and Fournier (2007); and the following using the 1995 survey in combination with the 2002 survey: Braunstein and Brenner (2007) and Li and Gustafsson (2008).
} 
rank system. We divide such workers into workers in the non-covered sector ("Non-covered workers" for short) and the much smaller category self-employed, which includes private owners ("self-employed" for short). Workers in work units where the rank system is applied are divided into three categories: High-rank workers include those who have senior professional level and senior cadre level (Chuzhang) and higher. This means that this category includes a typical head of a county and persons with higher rank in the administrative system such as professors at research institutes. Middle-rank workers include the middle rank of professional and cadre (Kezhang) levels. Typical examples are teachers at secondary schools and engineers. Workers in the covered sector not belonging to either of these two categories are categorized as low-rank workers.

/Table 1 about here/

Table 1 reports sample sizes and the relative size of the six categories for 1995 and 2002. Some changes across years are large. Not surprisingly, the proportion of low-rank workers has decreased. Actually, the proportion has more than halved, that is from 38 percent of the population in 1995 to only 16 percent in 2002. In contrast, the proportion of non-workers increased from as low as 5 percent in 1995 to as high as 28 percent in 2002. ${ }^{8}$ There is also an increase in the self-employment category (up to 3 percent), while the proportion of workers in the non-covered sector remained more or less unchanged (the proportion went from 36 to 37 percent). High-rank workers made up 3 percent of people in work-active ages in 2002 while middle-rank persons accounted for 13 percent. These percentages are only slightly lower than in 1995. Thus, as evaluated by their numbers, the categories of high-ranked workers and middle-ranked workers have remained relatively unchanged during this period of transition. High-ranked workers have thus become a much larger proportion of all ranked workers, a change most probably due to a lesser risk of being laid off.

/Table 2 about here/

In Table 2 we learn that the six categories differ along several characteristics. Particularly striking is that high-rank workers are the longest educated and the oldest. For example, in 2002 high-rank workers were on average almost seven years older than low-ranked workers, and they

\footnotetext{
${ }^{8}$ The composition of non-workers was in 1995 /2002: Early-retired 62 / 31 percent, unemployed 13 / 28 percent, students 13 / 28 percent, homemakers 5 / 8 percent and others 6 / 5 percent.
} 
had an average education that was 3.5 years longer; these differences were even larger in 1995. The age differences are due to age affecting promotion to higher rank, but also to a lesser extent due to higher-ranked workers exiting the labor force at higher ages than low-ranked workers. ${ }^{9}$ The table also shows that the shortest average education is found among the self-employed and among non-workers. High-ranked and middle-ranked workers are predominantly male and the dominance actually increased. As many as 81 percent of all high-rank workers were males in 2002. In contrast, women dominate among non-workers. There is also a large difference in membership in CPC across segments. Most striking is that while as few as 9 percent of self-employed individuals were members of CPC in 2002, the corresponding proportion among high-rank workers was as high as 68 percent. $^{10}$

The existence of the Hukou system puts barriers on rural to urban migration. Despite this, a considerable portion of the urban workers are rural born. The numbers are highest for high-rank workers, where according to our sample for 2002, as many as one-third are rural born. Such over-representation is understandable, as one route for receiving an urban hukou is via a long education and another by becoming a cadre. (See for example Deng and Gustafsson, 2006) The information collected in the 2002 survey includes parental background and Table 2 shows some clear signs of intergenerational relations in labor market segments.

\section{Being a high- or middle-rank worker}

We concentrate the analysis of factors affecting people's rank status to the 2002 survey which is richer in variables. ${ }^{11}$ The statistical analysis consists of estimating a Multinomial Probit model with low-rank worker as the omitted category; see Table 3 where we report marginal effects. Explanatory variables include education, age, ethnic status, gender, and dummies for membership in CPC, for being sent down during the Cultural Revolution, and for being born in rural China. There are also three dummies for parental characteristics. There are substantial differences across urban China with respect to job opportunities that are preserved by the hukou

\footnotetext{
${ }^{9}$ While the retirement for women in China is age 55, some high-rank women can continue to work after reaching this age. Also a few high-rank men can continue to work after the general retirement age of 60 .

${ }^{10}$ Using data from CHIP 1985, 1995 (the same as here), and 1999, Appleton et al (2008) have studied the determinants of CPC membership, as well as its income consequences. They find that the following characteristics positively affect the probability of being a party member: male sex, experience (with declining force), education and being employed in the government sector. Being employed in education has a negative coefficient.

${ }^{11}$ However, the survey does not contain information on each individual's work history (event data). Thus we are not able to analyze for example the process of promotion from low to middle rank or from middle to high rank.
} 
system. Therefore we include one continuous variable measuring the employment rate in the city where the respondent resides and another measuring the city's average per capita income (both are calculated from the data), as well as ten province dummies. In order to glean knowledge on changes over time, for 1995 as well as for 2002 we have used a specification containing only variables that are available for 1995. These results are shown in the Appendix.

\section{/Table 3 about here/}

As could be expected, education increases the probability of having a high rank as well as having a middle rank, with the largest influence on high rank. Conversely, education negatively affects the probability of being in sectors self-employed and a non-worker. Age positively and at a declining rate affects the probability of being a middle-rank worker, and particularly strongly affects the probability of being a high-rank worker. ${ }^{12}$ CPC party membership positively affects the probability of having high and middle rank or working in the non-covered sector while negatively affects the probability of being in other states. ${ }^{13}$

Being male positive affects the probability of having high rank, and negatively affects the probability of being a worker in the non-covered sector or being a non-worker. Our analysis thus confirms the existence of some clear gender differences in the urban Chinese labour market. Keeping other characteristics constant, males are more likely to be high-rank workers and less likely to be working in the non-covered sector or to be non-employed. This reflects most likely not only the household's, but also the work unit's preferences and decisions which in turn can reinforce each other. In most countries it is more typical for males to specialize in market work, while females specialize in housework. While by international standards such divisions of labour within the household were small in pre-reform urban China, there are more recent signs of increased disparities. Since the mid-90s labor force participation rates among women approaching the general retirement age decreased more rapidly than among males (see Li and Gustafsson, 2008).

In contrast to the influence of gender there is less evidence of ethnic minority status affecting

\footnotetext{
12 The age profile is actually steeper in 2002 than in 1995, see the Appendix.

${ }^{13}$ The specification reported in Table 3 assumes that causality runs from party membership to labor market status. It is interesting to see that if this is not accepted and therefore the model excluding the party member dummy is re-estimated, estimates for all other variables are surprisingly unchanged.
} 
work status. ${ }^{14}$ More evidence of influence is found for the migration experience. If the person was sent down to the countryside during the Cultural Revolution, the probability of being low ranked is increased. One interpretation is that the experience of being sent down has locked the person into a low-rank job and made it difficult to advance within the work unit or to find earnings possibilities outside it. The reasons for such situations remain to be investigated, but one can speculate that being sent down entails long-lasting negative consequences on networks useful for job-promotion and effecting change. ${ }^{15}$ Finally we report some (not strong) indicators of direct intergenerational linkages in labor market position. For example having a parent who is (or was) a cadre or professional increases the probability of being a high-rank worker.

\section{Personal income: Average, inequality and determinants}

When analyzing income in this section, we concentrate on personal income. That is, we add income from various sources and use the individual as income receiving unit as well as analytic unit. Personal income does not include subsidies in kind such as access to subsidized housing or high quality health care at low or no cost, benefits that to a large extent were phased out during the period studied here. Starting in Table 4, we report means for the six categories defined in Section 4 for the two years under study.

/Table 4 about here/

High-rank workers have the highest means and they are followed by middle-rank workers. Not surprisingly, non-workers have the lowest average personal incomes. Also of note is that the means changed rather differently from 1995 to 2002. While the average for all people in the studied group rose by 33 percent, average income for the heterogeneous category of non-workers fell by 24 percent. While it is beyond the scope of this paper to analyze the changes for the non-workers, it should be understood that the rapid expansion of the category was due not only to many middle-aged people being laid off, but also due to an ever larger proportion of young adults remaining in education (on the latter see Connelly and Zheng, 2007). In contrast high-rank workers gained on average as much as 91 percent and they were followed

\footnotetext{
${ }^{14}$ The only exception is a positive coefficient for the self-employment state. However, we also note that in the models estimated for 1995, reported in the Appendix, the corresponding is not the case.

${ }^{15}$ These results are consistent with findings reported by Zhou and Hou (1999) who report that a "sent down" experience negatively affected personal income among females in 1993 (but not in earlier years investigated).
} 
by middle-rank workers whose average income increased by 71 percent. The increases for low-rank workers and workers in the not-covered sector were somewhat lower.

Does the same picture emerge if studying household income per person rather than personal income? When moving from individuals to households in the analysis, we also consider how households are composed with respect to labour market segment. In a hypothetical situation all gains in personal income for high-rank persons could be diluted if such persons were sharing the incomes with the increased number of non-workers (students, housewives). However, Table A1 shows that this is not a good first approximation of the real situation. The table also shows that changes in average disposable income per capita across categories are smaller than the changes in personal incomes. The same table also shows the large importance of other household members' personal income for the development of living standard of non-workers. Although average personal income for non-workers decreased from 1995 to 2002 (Table 4), average disposable household income per capita increased (but by a considerably lower percentage than for the entire group under study).

We have thus found indicators of high-rank workers belonging to the winners and the growing number of non-workers to the losers, as the numbers could mean that the gaps in remuneration between non-ranked workers on one hand and high- and middle-ranked workers on the other have increased. However, the results could be given another interpretation. During the period studied, several in-kind benefits received by workers were phased out. This change was probably to a larger disadvantage for high- and middle-ranked workers, and the increased monetary compensation might compensate, to a lower or higher degree for benefits no longer received. If the only reason for the increased gap in personal income between workers of different categories is changes in the form of remuneration, we would not expect to find increased gaps between the categories in other economic spheres. However, increased disparities across labour market categories are shown in our data. In the appendix we present statistical information showing increased gaps from 1995 to 2002 in terms of household wealth per capita as well as in housing space per capita.

/Table 5 about here/

Table 5 reports income inequality in personal income measured by the Gini coefficient and the Mean Logarithmic Deviation index for the entire group studied as well as for each category for 
1995 and 2002. The latter has the useful property that inequality can be expressed as the weighted sum of the inequality within each population subgroup plus the inequality between subgroups (the inequality arising from if no inequality existed within each group). ${ }^{16}$ Several observations can be made. First, income inequality in the studied group as a whole has definitly increased. For example, the Gini rose from 0.322 to 0.449 , a rather rapid increase. Second, income inequality within the categories self-employed and non-workers is the largest while the opposite is the case for high-rank workers and middle-rank workers. Third, although income inequality has increased within the categories high rank, middle rank and non-workers, differences in means have grown even faster, and polarization has increased. This is shown as the proportion of total income inequality (measured by the MLD index) that can be attributed to differences in mean income across the seven categories has almost doubled, from 12 percent in 1995 to 20 percent in 2002. In other words, a person's labour market category more strongly predicts the level of personal income in 2002 than in 1995.

While there were thus large impulses towards increased income inequality coming from the labour market, it is rather interesting to see that at the household level they have been totally dampened. Appendix 1 shows that while the Gini in personal income went up, the Gini for household income per capita moved down from 0.332 to 0.317 . The same table also shows that inequality in household wealth per capita and also in housing space decreased from 1995 to 2002. At the household level, and for a measure that is most relevant for welfare assessments, there is thus no sign of increased inequality in urban China for the period 1995 to 2002. The reason for this warrants a study of its own.

To better understand how status as high rank and middle rank affect personal income and how various factors affect income among high-rank and middle-rank workers, we have conducted two different analyses both concentrating on the income determination among all workers. ${ }^{17}$ In Table 6 we report results from regression analyses using three specifications for each year and log income as the dependent variable. The first includes as explanatory variables education and age, dummies for being sent down and ethnic status, and three dummies for combinations of gender and marital status. The specification also includes as control variables, one continuous variable indicating employment rate in the city as well as another continuous variable

\footnotetext{
${ }^{16}$ For a definition of the indices see for example Sen (1997 p 31 and 140).

${ }^{17}$ We exclude non-workers from the dataset analyzed as other processes determine their personal income and the focus of the paper is on people who work.
} 
measuring average per capita income in the city. In the second specification we add as explanatory variable a dummy for working in the covered sector while in the third sector we add dummies for high rank, middle rank, self-employment and being employed (the omitted category is thus that of being a low-rank worker in the covered sector).

\section{/Table 6 about here/}

The following comments can be made: First, the coefficient of education has increased from 1995 to 2002. This finding is consistent with what has been reported from the same data when estimating earnings functions and from other data analyzing the relation between education and earnings. ${ }^{18}$ When adding the dummy for covered sector the coefficient is positive both years, and has actually increased. In specification three we find that such changes are not uniform across workers in the sector. Of great interest to this paper is that the coefficients of high rank and middle rank are both positive and estimated with high t-statistics. They are higher in 2002 than in 1995. The coefficient for high rank increased from 0.13 in 1995 to 0.30 in 2002 while the coefficient for middle rank went from 0.11 to $0.19 .{ }^{19}$ Thus rank seems to have an independent and increasing effect on personal income.

Comparing coefficient for education in specifications one and two we find them to be almost odemtoal. When moving to specification three, the coefficient for education is lowered, but only slightly. The indirect effect of education on personal income via sector is very small and the one channeled via rank status is not particularly high. In contrast, the results indicate that the payoff from being employed in the covered sector for a low-rank worker (compared to working in the non-covered sector) decreased across years to become rather small. Finally, the dummy for self-employed in specification 3 went from positive and significant in 1995 to being insignificant in 2002.

In Table 6 we report relatively large coefficients for the dummy married male (not-married male as the omitted category) and they are estimated with high t-statistics. In contrast, coefficients for not-married female and married female are both small and many estimated with low t-statistics. The coefficients for party membership are all positive and estimated with high t-values. The estimates also indicate that, not surprisingly, average city income has a positive

\footnotetext{
${ }^{18}$ For the former see for example Knight and Song (2008) and for the latter see Zhang et al. (2005).

${ }^{19}$ Our estimates for 1995 are similar to those for 1993 reported by Zhou (2004) using a similar specification.
} 
effect on personal income. There are no indications of ethnic minority status or being sent down to the countryside during the Cultural Revolution affecting personal income.

/Table 7 about here /

In the second exercise we also analyze all workers but disaggregate the samples for 1995 and 2002 by the five labor market segments of workers and estimate the same specification for each. This we do in order to better understand income determination within categories, and to investigate possible changes over time. The following comments can be made: Coefficients of education are all positive, with only one exception (self-employed 1995) estimated with t-values higher than 2. They tend to be higher in 2002 than in $1995 .^{20}$ In all categories, with the exception of self-employed, the positive coefficient of party membership as well as age, and the negative of age squared are estimated with high t-values. The coefficient for female gender are all negative, and with only one exception (middle-rank females in 2002), estimated with high t-statistics. The highest negative effect is found among the self-employed. Thus, not surprisingly, the process of income determination among self-employed seems to differ in many respects from that of wage earners.

\section{Conclusions}

In this paper we have claimed that greater attention should be paid to the ranking system when trying to understand the Chinese labour market and its changes. Although larger proportions of people of working age than previously are not covered by the ranking system, in 2002 around 3 percent of persons of working age belonged to the high rank category as defined here and another 14 percent belonged to the middle rank category. These proportions are actually similar to those calculated for 1995. Using microdata from surveys covering large parts of urban China, we have investigated factors essential for belonging to each of the previously mentioned categories as well as to four other categories, by estimating a multinomial probit model. We have also investigated how personal income, disposable per capita income (averages and inequality), household wealth per capita and housing space per capita changed from 1995 to 2002 for the six categories. Further we studied the income generation process by estimating

\footnotetext{
${ }^{20}$ In Table 7 the coefficient for education is higher among non-covered workers than among high rank-worker, middle-rank worker and low-rank worker.
} 
regression models.

Not surprisingly, we have confirmed that presence of a long education and relatively high age make it more likely for a person to have a high or middle rank than a low rank. China's high-rank workers compose a men's club, to a large extent, as in 2002 there were four males for every female. We have reported that there is relatively little inequality in personal income among persons of high and middle rank, though it is increasing. A main conclusion is that the old elite of workers of high rank have not only succeeded in keeping their money income position, they have actually experienced increases in relation to other persons of work-active ages. Workers of high rank, and to a lesser degree of middle rank, are the winners. This judgment is based on the analysis of personal income, disposable income per capita, household income per capita and housing space per capita. During the period 1995 to 2002, the losers are the increasingly large group of non-workers.

In 2002, the distribution of personal income in urban China among people of work-active ages was more polarized than in 1995, based on the categories used here. During this period, the rates of return to education increased. However, the regression analysis reported here indicates that this is far from a full explanation for why workers of high rank, and to some extent middle rank, have fared as well as they have. Our analysis indicates that gender differences in urban China consist of lesser probability for women having high-rank jobs, and of lower payoffs for characteristics within the segment where women work. Finally, our study has illustrated that a strong impulse towards more inequality arising from the labor market was significantly dampened at the household level. 


\section{References:}

Appleton, S., Song, L., Xia, Q.J. (2005) "Has China Crossed the River? The Evolution of Wage Structure in urban China during Reform and Retrenchment", Journal of Comparative Economics, 33, $644-663$.

Appleton, S., Knight, J., Song, L., Xia, Q. (2008) “The Economics of Communist Party Membership: The Curious Case of Rising Numbers and Wage Premium during China's Transition”, Institute for the Study of Labor, Discussion Paper No. 3454. Bonn, Germany.

Bian, Y and Logan, J. (1996) "Market Transition and the Persistence of Power: The Changing Stratification System in urban China”, American Sociological Review, 61, (5), 739 - 758.

Bian, Y. and Zhang, Z. (2004) "Urban Elites and Income Differential in China 1988 - 1995”, Japanese Journal of Political Sciences, 5, 51 - 68.

Bishop, J., Luo, F, and Wang, W (2005) "Economic Transition, Gender Bias, and the Distribution of Earnings in China”, Economics of Transition, 13, 239 - 259.

Braunstein, E. and Brenner, M. (2007) "Foreign Direct Investment and Gendered Wages in Urban China”, Feminist Economics, 13, 213 - 237.

Chao, Y. and Nee, V. (2005) "Remaking Inequality: Institutional Change and Income Stratificationin Urban China”, Journal of the Asia Pacific Economy, 10, 463 - 485.

Connelly, D. and Zheng, Z (2007) “Enrolment and Graduation Patterns as China's Reforms Deepened, 1990 - 2000” Chapter 5 in Hannum, E. and Park, A. (Eds) Education and Reform in China, Oxon: Routledge.

Démurger, S., Fournier, M. and Chen, Y. (2007) “The Evolution of Gender Earnings Gap and Discrimination in Urban China 1988 - 95”, Developing Economics, 45, 97 - 121.

Deng, Q. and Gustafsson, B. (2006) “China’s Lesser Known Migrants”, Institute for the Study of Labour, Bonn, Germany, Working Paper No 2152.

Gustafsson, B. och Li S. (2000) "Economic Transformation in Urban China and the Gender Wage Gap", Journal of Population Economics, 13, 305 - 329.

Gustafsson, B and Li, S. (2001) "The Anatomy of Rising Earnings Inequality in Urban China”, Journal of Comparative Economics, 29, 118 - 135.

Knight, J. and Song, L. (2003) “Increased Urban Wage Inequality in China”, Economics of Transition, 11, $597-619$.

Knight, J. and Song, L. (2008) “China’s Emerging Wage Structure, 1995 - 2002”, in Gustafsson, B, Li, S., Sicular, T. (eds). 2008) Inequality and Public Policy in China, Cambridge University Press.

Li, S, Luo, C, Wei, Z and Yue, X. (2008) "The 1995 and 2002 Household Surveys: Sampling Methods and Data Description” in Gustafsson, B., Li, S., Sicular, T. (eds) (2008) Inequality and Public Policy in China, Cambridge University Press. 
Li, S. and Gustafsson, B. (2008), "Unemployment, Earlier Retirement and Changes in the Gender Income Gap in Urban China 1995 - 2002”, in Gustafsson, B, Li, S., Sicular, T. (eds). Inequality and Public Policy in China, Cambridge University Press.

Luo, J. and Lu W., (2005), “The Construction of Technical Title System and Reform Thoughts in New China”, Jiangxi Social Sciences, 11, 250-255 (In Chinese).

Nee, V. (1989) "A Theory of Market Transition: From Redistribution to Market in State Socialism”, American Sociological Review, 54 (5), 663 - 681.

Sen, A. (1997) On Economic Inequality. Expanded edition with a substantial annexe by James E. Foster and Amartya Sen, Oxford: Clarendon.

Tang S. (2006), "Social Mobility, Position Market and Economy Development”, Social Sciences in China, 3, 85-97 (In Chinese).

Walder, A. (1995) "Career Mobility and the Communist Political Order", American Sociological Review, 60, (3) 309 - 328.

Walder, A. (2003) “Elite Opportunity in Transitional Economies”, American Sociological Review, 68, (6), 899 - 916.

Walder, A., Li, B., Treiman, D. (2000) "Politics and Life Changes in a State Socialist Regime: Dual Career Paths into the Urban Chinese Elite, 1949 to 1996”, American Sociological Review, 65, $191-209$.

Zhang L. and Yuan L. (2007), “Cause of Formation for Civil Servants' Revenue Decision Mechanism in China: An Explanation Based on Labor Market Segmentation Theory”, Journal of Beijing Jiaotong University (Social Sciences Edition), 6, 41-45 (In Chinese).

Zhang, J., Zhao, Y., Park, A. och Song, X. (2005) "Economic Returns to Schooling in Urban China”, Journal of Comparative Economics, 33, 730 - 752.

Zhou, X. (2000) "Economic Transformation and Income Inequality in Urban China: Evidence from Panel Data”, American Journal of Sociology, 105, 1135 - 76.

Zhou, X. (2004) The State and Life Changes in Urban China, Cambridge: Cambridge University Press.

Zhou, X., Tuma, N.B. and Moen, P. (1997) "Institutional Change and Job-shifts Patterns in Urban China, 1949 - 1994”, American Sociological Review, 62, 339 - 365.

Zhou, X., Hou, L. (1999) "Children of the Cultural Revolution: The State, and the Life Course in the People’s Republic of China, American Sociological Review, 64, 12 - 36. 
Table 1. Various categories 1995 and 2002

\begin{tabular}{|c|c|c|c|c|c|c|c|c|c|c|c|c|c|c|}
\hline & $\begin{array}{l}\text { High } \\
\text { rank }\end{array}$ & $\begin{array}{l}\text { Percent- } \\
\text { age }\end{array}$ & $\begin{array}{l}\text { Middle } \\
\text { rank }\end{array}$ & $\begin{array}{l}\text { Percent- } \\
\text { age }\end{array}$ & $\begin{array}{l}\text { Other wage } \\
\text { earners in } \\
\text { covered } \\
\text { sector }\end{array}$ & $\begin{array}{l}\text { Percent- } \\
\text { age }\end{array}$ & $\begin{array}{l}\text { Self- } \\
\text { employed } \\
\text { or private } \\
\text { owner }\end{array}$ & $\begin{array}{l}\text { Percent- } \\
\text { age }\end{array}$ & $\begin{array}{l}\text { Wage earners } \\
\text { in non-covered } \\
\text { sector }\end{array}$ & $\begin{array}{l}\text { Percent- } \\
\text { age }\end{array}$ & $\begin{array}{l}\text { Non- } \\
\text { work } \\
\text { er }\end{array}$ & $\begin{array}{l}\text { Percent- } \\
\text { age }\end{array}$ & Total & $\begin{array}{l}\text { Percent- } \\
\text { age }\end{array}$ \\
\hline 1995 & 631 & 4.16 & 2394 & 15.78 & 5723 & 37.72 & 187 & 1.23 & 5437 & 35.83 & 802 & 5.29 & $\begin{array}{l}1517 \\
4\end{array}$ & $100 \%$ \\
\hline 2002 & 504 & 3.34 & 1975 & 13.11 & 2347 & 15.58 & 468 & 3.11 & 5511 & 36.57 & 4264 & 28.30 & $\begin{array}{l}1506 \\
9\end{array}$ & $100 \%$ \\
\hline
\end{tabular}

Note: High rank includes those who are at senior professional level and senior cadre level (Chuzhang and above); middle rank includes middle rank of professional and cadre (Kezhang); Other wage earners in same sectors

Source: Authors calculation from CHIP, urban survey. 
Table 2 Characteristics of different categories 1995 and 2002

\begin{tabular}{|c|c|c|c|c|c|c|}
\hline & $\begin{array}{l}\text { High } \\
\text { rank }\end{array}$ & $\begin{array}{l}\text { Middle } \\
\text { rank }\end{array}$ & $\begin{array}{l}\text { Other wage } \\
\text { earners in same } \\
\text { units }\end{array}$ & $\begin{array}{l}\text { Self-employed or } \\
\text { private owner }\end{array}$ & $\begin{array}{l}\text { Workers in not } \\
\text { covered sector }\end{array}$ & $\begin{array}{l}\text { Non- } \\
\text { worker }\end{array}$ \\
\hline \multicolumn{7}{|l|}{1995} \\
\hline Average education. Years & 13.93 & 12.41 & 9.78 & 9.15 & 10.27 & 8.36 \\
\hline Average age. Years & 49.92 & 44.13 & 38.48 & 38.36 & 34.05 & 44.87 \\
\hline Average per capita city income (Yuan) & 5414 & 5073 & 4854 & 4636 & 4966 & 5520 \\
\hline Average city employment rate (percent) & 80.68 & 81.45 & 81.21 & 79.60 & 81.31 & 80.25 \\
\hline Percentage Males & 74.48 & 58.65 & 50.50 & 50.27 & 43.20 & 28.55 \\
\hline Percentage Females & 25.52 & 41.35 & 49.50 & 49.73 & 56.80 & 71.45 \\
\hline $\begin{array}{l}\text { Sent down during the Cultural } \\
\text { Revolution. Percent. }\end{array}$ & 11.89 & 22.60 & 20.32 & 10.16 & 15.85 & 7.86 \\
\hline Member of CPC. Percent. & 66.09 & 49.75 & 16.16 & 9.09 & 12.45 & 10.22 \\
\hline $\begin{array}{l}\text { Number of observations } \\
2002\end{array}$ & 361 & 2391 & 5688 & 186 & 4123 & 802 \\
\hline Average individual total income (Yuan) & 20099 & 15461 & 10625 & 10474 & 11042 & 2634 \\
\hline Average education, Years & 14.05 & 13.30 & 10.46 & 9.45 & 10.96 & 9.9 \\
\hline Average age. Years. & 47.12 & 42.48 & 40.46 & 39.80 & 40.42 & 36.94 \\
\hline $\begin{array}{l}\text { Average city per capita income } \\
\text { (Yuan) }\end{array}$ & 7973 & 7724 & 8034 & 7515 & 8108 & 7863 \\
\hline Average city employment rate & 68.20 & 69.54 & 68.56 & 69.09 & 68.73 & 66.80 \\
\hline Percent of urban born & 67.06 & 69.87 & 82.45 & 77.14 & 78.73 & 82.90 \\
\hline Percentage Male & 80.95 & 63.54 & 58.24 & 57.48 & 46.80 & 35.13 \\
\hline Percentage Female & 19.05 & 36.46 & 41.76 & 42.52 & 53.20 & 64.87 \\
\hline $\begin{array}{l}\text { Sent down during the Cultural } \\
\text { Revolution. Percent }\end{array}$ & 21.23 & 18.33 & 20.07 & 12.82 & 16.62 & 11.61 \\
\hline Member of CPC. Percent. & 68.25 & 53.92 & 19.09 & 8.55 & 23.04 & 9.64 \\
\hline $\begin{array}{l}\text { Percentage of at least one parent having } \\
\text { high education }\end{array}$ & 46.83 & 50.58 & 38.73 & 37.82 & 37.91 & 29.81 \\
\hline $\begin{array}{l}\text { Percentage of at least one parent being } \\
\text { professional or cadre }\end{array}$ & 41.25 & 38.66 & 28.52 & 24.73 & 27.47 & 21.58 \\
\hline $\begin{array}{l}\text { Percentage of parents working in same } \\
\text { units but not professional or cadre. }\end{array}$ & 30.99 & 35.25 & 51.93 & 36.11 & 46.04 & 47.94 \\
\hline $\begin{array}{l}\text { Percentage of parents self- employed or } \\
\text { private owner. }\end{array}$ & 1.21 & 1.35 & 1.73 & 3.94 & 2.11 & 2.66 \\
\hline $\begin{array}{l}\text { Percentage parents working in } \\
\text { non-covered sector }\end{array}$ & 26.56 & 24.74 & 17.82 & 35.23 & 24.38 & 27.82 \\
\hline Number of observations & 504 & 1975 & 2346 & 468 & 5503 & 4264 \\
\hline
\end{tabular}

Note: Income variables are expressed in prices of 2002 (by CPI).

Source: Authors calculation from CHIP, urban survey. 
Table 3 Marginal effects of determinants of different labor market categories 2002

\begin{tabular}{|c|c|c|c|c|c|c|c|c|c|c|c|c|}
\hline & \multicolumn{2}{|c|}{ High rank } & \multicolumn{2}{|c|}{ Middle rank } & \multicolumn{2}{|c|}{ Low rank } & \multicolumn{2}{|c|}{$\begin{array}{l}\text { Self-employed } \\
\text { or private } \\
\text { owner }\end{array}$} & \multicolumn{2}{|c|}{$\begin{array}{l}\text { Not covered } \\
\text { worker }\end{array}$} & \multicolumn{2}{|c|}{ Non-worker } \\
\hline & Coef. & $\begin{array}{c}Z \text { Z- } \\
\text { value }\end{array}$ & Coef. & $\begin{array}{c}\mathrm{Z} \text { - } \\
\text { value }\end{array}$ & Coef. & $\begin{array}{c}Z \text { Z- } \\
\text { value }\end{array}$ & Coef. & $\begin{array}{c}\mathrm{Z}- \\
\text { value }\end{array}$ & Coef. & $\begin{array}{c}Z \text { Z- } \\
\text { value }\end{array}$ & Coef.t & $\begin{array}{c}\mathrm{Z}- \\
\text { value }\end{array}$ \\
\hline $\begin{array}{l}\text { Education } \\
\text { years }\end{array}$ & 0.0108 & 18.31 & 0.0308 & 32.56 & -0.0113 & -11.19 & -0.0046 & -9.52 & -0.0010 & -0.73 & -0.0247 & -24.04 \\
\hline Age & 0.0144 & 6.62 & 0.0344 & 12.89 & 0.0288 & 13.17 & 0.0081 & 6.8 & 0.0120 & 4.51 & -0.0976 & -74.13 \\
\hline Age square & -0.0001 & -5.86 & -0.0004 & -12.38 & -0.0004 & -14.34 & -0.0001 & -7.25 & -0.0002 & -5.51 & 0.0012 & 69.85 \\
\hline $\begin{array}{l}\text { Party } \\
\text { member }\end{array}$ & 0.0208 & 5.54 & 0.0779 & 11.26 & -0.0156 & -2.15 & -0.0209 & -9.13 & 0.0319 & 3.16 & -0.0941 & -12.56 \\
\hline $\begin{array}{l}\text { Employment } \\
\text { rate of the } \\
\text { residential } \\
\text { city }\end{array}$ & 0.0000 & -0.08 & 0.0025 & 6.52 & 0.0011 & 2.37 & 0.0000 & -0.21 & 0.0021 & 3.56 & -0.0057 & -11.84 \\
\hline $\begin{array}{l}\text { Average city } \\
\text { per capita } \\
\text { income }\end{array}$ & 0.0000 & 2.5 & 0.0000 & -3.8 & 0.0000 & 4.12 & 0.0000 & -5.03 & 0.0000 & 1.84 & 0.0000 & -1.88 \\
\hline Send down & -0.0041 & -1.26 & -0.0049 & -0.75 & 0.0262 & 2.98 & -0.0062 & -1.66 & -0.0155 & -1.43 & 0.0045 & 0.5 \\
\hline Minority & -0.0032 & -0.45 & 0.0049 & 0.37 & -0.0273 & -1.91 & 0.0374 & 3.34 & 0.0067 & 0.33 & -0.0184 & -1.21 \\
\hline Male & 0.0269 & 6.69 & 0.0352 & 6.17 & 0.0755 & 10.97 & 0.0184 & 5.13 & -0.0185 & -2.38 & -0.1375 & -27.22 \\
\hline Urban born & -0.0103 & -3.5 & -0.0248 & -4.37 & 0.0204 & 2.59 & -0.0032 & -0.95 & -0.0207 & -2.12 & 0.0386 & 4.7 \\
\hline $\begin{array}{l}\text { Education } \\
\text { level of } \\
\text { parents }\end{array}$ & -0.0007 & -0.23 & 0.0205 & 3.43 & 0.0010 & 0.15 & 0.0042 & 1.21 & -0.0052 & -0.59 & -0.0198 & -2.86 \\
\hline $\begin{array}{l}\text { Parents are } \\
\text { cadre or } \\
\text { professional }\end{array}$ & 0.0079 & 2.12 & 0.0040 & 0.66 & 0.0035 & 0.47 & -0.0004 & 1.82 & -0.0039 & -0.4 & -0.0110 & -1.39 \\
\hline $\begin{array}{l}\text { Parents are } \\
\text { self-employe } \\
\text { dor private } \\
\text { owner }\end{array}$ & -0.0085 & -0.89 & -0.0312 & -1.86 & -0.0179 & -0.89 & 0.0228 & 1.09 & 0.0168 & 0.62 & 0.0180 & 0.87 \\
\hline $\begin{array}{l}\text { Parents are } \\
\text { non-worker }\end{array}$ & -0.0032 & -0.45 & -0.0139 & -1.04 & -0.0418 & -3.1 & 0.0089 & -18.03 & 0.0375 & 1.9 & 0.0123 & 0.85 \\
\hline Observations & 504 & & 1975 & & 2346 & & 468 & & 5503 & & 4264 & \\
\hline
\end{tabular}

Source: CHIP, urban survey.

Table 4 Personal income among various labor market categories 1995 and 2002. Yuan (as in 2002).

\begin{tabular}{|c|c|c|c|c|c|c|c|}
\hline & $\begin{array}{l}\text { High } \\
\text { rank }\end{array}$ & $\begin{array}{l}\text { Middle } \\
\text { rank }\end{array}$ & $\begin{array}{l}\text { Other wage earners } \\
\text { in same sectors }\end{array}$ & $\begin{array}{l}\text { Self-employed or } \\
\text { private owner }\end{array}$ & $\begin{array}{l}\text { Wage earners } \\
\text { elsewhere }\end{array}$ & $\begin{array}{l}\text { Non- } \\
\text { worker }\end{array}$ & Total \\
\hline 1995 & & & & & & & \\
\hline $\begin{array}{l}\text { Total China } \\
2002\end{array}$ & 10508 & 9011 & 6584 & 7570 & 6780 & 3444 & 7073 \\
\hline Total China & 20099 & 15461 & 10625 & 10474 & 11042 & 2634 & 9461.70 \\
\hline $\begin{array}{l}\text { Percentage } \\
\text { change }\end{array}$ & +91 & +72 & +61 & +38 & +63 & -24 & +34 \\
\hline
\end{tabular}

Source: Authors calculation from CHIP, urban survey. 
Table 5 Income inequality among various labor market categories 1995 and 2002

\begin{tabular}{|c|c|c|c|c|}
\hline & MLD & MLD & Gini & Gini \\
\hline Decomposition of individual total income & 1995 & 2002 & 1995 & 2002 \\
\hline Total urban China & 0.1901 & 0.3707 & 0.3223 & 0.4486 \\
\hline Within all groups & 0.1687 & 0.2232 & & \\
\hline Among: high rank individuals & 0.0906 & 0.1312 & 0.2329 & 0.2742 \\
\hline Middle rank individuals & 0.1315 & 0.1466 & 0.2544 & 0.2836 \\
\hline Other wage earners in same units & 0.1633 & 0.1591 & 0.3011 & 0.3068 \\
\hline Self-employed or private owner & 0.3155 & 0.3146 & 0.4208 & 0.4112 \\
\hline Not covered employed workers & 0.2009 & 0.1924 & 0.3318 & 0.3341 \\
\hline Non-worker & 0.3186 & 0.7825 & 0.4217 & 0.6334 \\
\hline Between different groups & 0.0174 & 0.1476 & & \\
\hline Between different groups as percent of total index & 9.15 & 39.82 & & \\
\hline Number of observations & 15174 & 15069 & & \\
\hline
\end{tabular}

Source: Authors calculation from CHIP, urban survey. 
Table 6 Income functions 1995 and 2002.

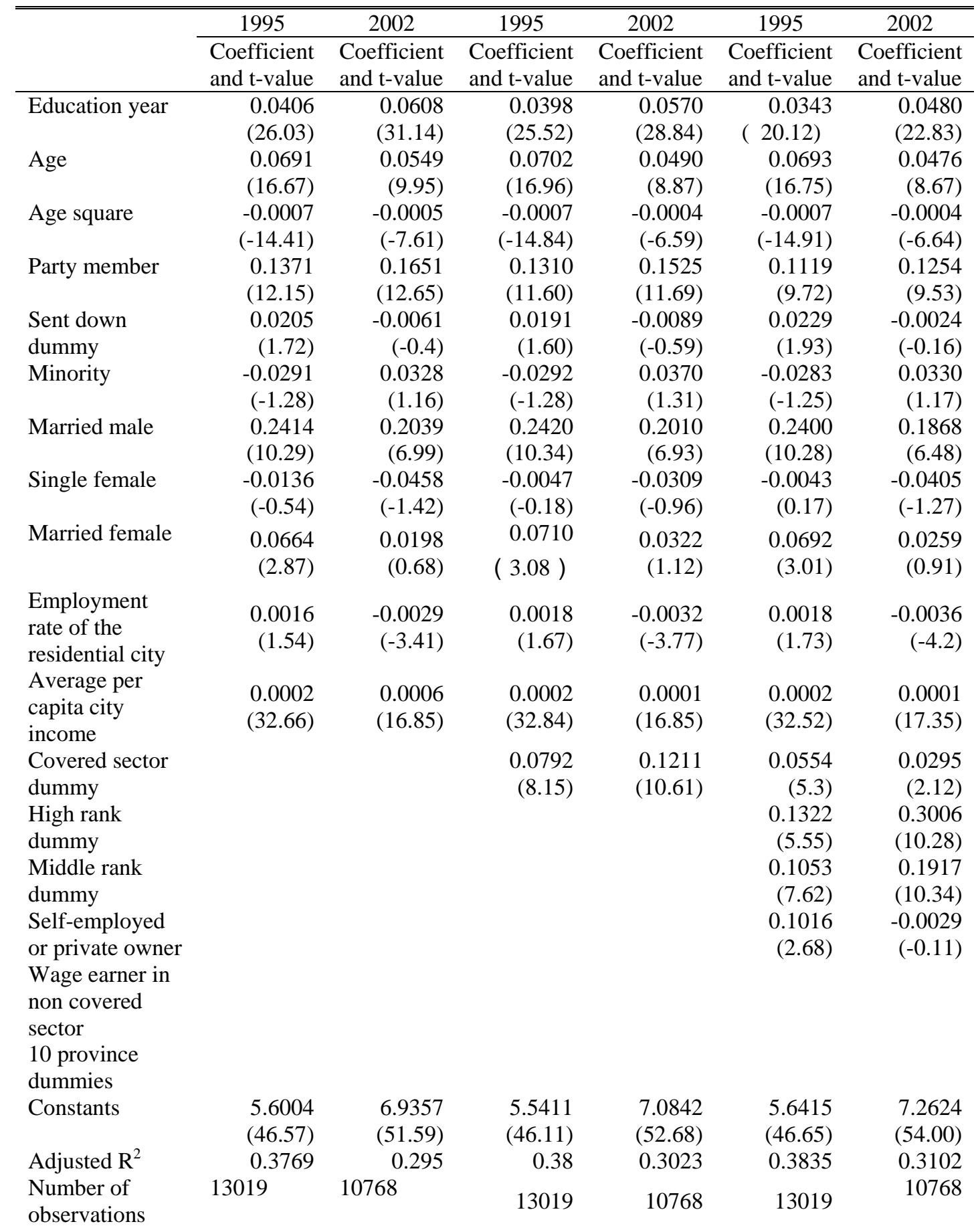

Note: Dependent variable is log personal income. The omitted category is work in same sectors. The analysis is restricted to workers.

Source: CHIP, urban survey. 
Table 7 Income functions for different labor market categories 1995 and 2002

\begin{tabular}{|c|c|c|c|c|c|}
\hline & $\begin{array}{l}\text { High rank } \\
\text { worker }\end{array}$ & $\begin{array}{l}\text { Middle rank } \\
\text { worker }\end{array}$ & $\begin{array}{l}\text { Low rank } \\
\text { worker }\end{array}$ & Self-employed & $\begin{array}{l}\text { Not covered } \\
\text { worker }\end{array}$ \\
\hline 1995 & $\begin{array}{l}\text { Coefficient, } \mathrm{t} \\
\text { statistics value }\end{array}$ & $\begin{array}{l}\text { Coefficient, } \mathrm{t} \\
\text { statistics value }\end{array}$ & $\begin{array}{l}\text { Coefficient, } \mathrm{t} \\
\text { statistics value }\end{array}$ & $\begin{array}{l}\text { Coefficient, } \mathrm{t} \\
\text { statistics value }\end{array}$ & $\begin{array}{l}\text { Coefficient, } t \\
\text { statistics value }\end{array}$ \\
\hline Education & $\begin{array}{c}0.0226 \\
(4.90)\end{array}$ & $\begin{array}{c}0.0143 \\
(4.90)\end{array}$ & $\begin{array}{c}0.0280 \\
(9.74)\end{array}$ & $\begin{array}{c}0.0143 \\
(0.68)\end{array}$ & $\begin{array}{c}0.0524 \\
(16.24)\end{array}$ \\
\hline Age & $\begin{array}{c}0.0644 \\
(3.89)\end{array}$ & $\begin{array}{c}0.0522 \\
(6.25)\end{array}$ & $\begin{array}{l}0.1049 \\
(21.28)\end{array}$ & $\begin{array}{c}0.0625 \\
(1.54)\end{array}$ & $\begin{array}{l}0.0942 \\
(13.75)\end{array}$ \\
\hline Age squared & $\begin{array}{c}-0.0006 \\
(-3.1)\end{array}$ & $\begin{array}{c}-0.0005 \\
(-5.70)\end{array}$ & $\begin{array}{l}-0.0012 \\
(-18.89)\end{array}$ & $\begin{array}{l}-0.0005 \\
(-1.01)\end{array}$ & $\begin{array}{l}-0.0010 \\
(-11.23)\end{array}$ \\
\hline Party member & $\begin{array}{l}0.0685 \\
(2.24)\end{array}$ & $\begin{array}{c}0.0952 \\
(5.98)\end{array}$ & $\begin{array}{c}0.1246 \\
(6.48)\end{array}$ & $\begin{array}{c}0.0976 \\
(0.5)\end{array}$ & $\begin{array}{c}0.1531 \\
(6.08)\end{array}$ \\
\hline Female & $\begin{array}{l}-0.0942 \\
(-2.87)\end{array}$ & $\begin{array}{c}-0.0733 \\
(-4.63)\end{array}$ & $\begin{array}{l}-0.1762 \\
(-12.81)\end{array}$ & $\begin{array}{c}-0.2911 \\
(-2.49)\end{array}$ & $\begin{array}{c}-0.1424 \\
(-7.91)\end{array}$ \\
\hline Sent down & $\begin{array}{c}-0.0246 \\
(-0.52)\end{array}$ & $\begin{array}{l}0.0015 \\
(0.08)\end{array}$ & $\begin{array}{l}0.0190 \\
(1.03)\end{array}$ & $\begin{array}{l}0.1256 \\
(0.66)\end{array}$ & $\begin{array}{c}0.0163 \\
(0.7)\end{array}$ \\
\hline $\begin{array}{l}\text { Employment } \\
\text { rate of city }\end{array}$ & $\begin{array}{l}-0.0057 \\
(-1.32)\end{array}$ & $\begin{array}{l}-0.0028 \\
(-1.52)\end{array}$ & $\begin{array}{l}0.0036 \\
(2.25)\end{array}$ & $\begin{array}{c}0.0028 \\
(0.20)\end{array}$ & $\begin{array}{c}0.0042 \\
(2.02)\end{array}$ \\
\hline $\begin{array}{l}\text { Average per } \\
\text { capita income } \\
10 \text { province } \\
\text { dummies }\end{array}$ & $\begin{array}{c}0.0001 \\
(4.91)\end{array}$ & $\begin{array}{l}0.0001 \\
(14.05)\end{array}$ & $\begin{array}{l}0.0002 \\
(22.67)\end{array}$ & $\begin{array}{r}0.0002 \\
(3.44)\end{array}$ & $\begin{array}{l}0.0001 \\
(15.55)\end{array}$ \\
\hline Constant & $\begin{array}{l}6.8994 \\
(11.56)\end{array}$ & $\begin{array}{l}7.1639 \\
(28.65)\end{array}$ & $\begin{array}{l}4.9943 \\
(29.26)\end{array}$ & $\begin{array}{l}6.0902 \\
(4.56)\end{array}$ & $\begin{array}{l}5.1631 \\
(23.81)\end{array}$ \\
\hline Adjusted R2 & 0.3487 & 0.3221 & 0.3217 & 0.2203 & 0.3555 \\
\hline $\begin{array}{l}\text { Number of } \\
\text { observations } \\
2002\end{array}$ & 631 & 2391 & 5688 & 186 & 4123 \\
\hline Education & $\begin{array}{l}0.0410 \\
(5.43)\end{array}$ & $\begin{array}{l}0.0267 \\
(5.83)\end{array}$ & $\begin{array}{l}0.0363 \\
(7.66)\end{array}$ & $\begin{array}{l}0.0335 \\
(2.52)\end{array}$ & $\begin{array}{l}0.0563 \\
(19.11)\end{array}$ \\
\hline Age & $\begin{array}{c}0.1071 \\
(3.4)\end{array}$ & $\begin{array}{c}0.0664 \\
(5.09)\end{array}$ & $\begin{array}{l}0.0904 \\
(9.09)\end{array}$ & $\begin{array}{l}0.0454 \\
(1.39)\end{array}$ & $\begin{array}{c}0.0555 \\
(9.03)\end{array}$ \\
\hline Age squared & $\begin{array}{c}-0.0011 \\
(-3.12)\end{array}$ & $\begin{array}{c}-0.0007 \\
(-4.76)\end{array}$ & $\begin{array}{l}-0.0010 \\
(-7.91)\end{array}$ & $\begin{array}{l}-0.0006 \\
(-1.47)\end{array}$ & $\begin{array}{l}-0.0005 \\
(-6.02)\end{array}$ \\
\hline Party member & $\begin{array}{l}0.1117 \\
(2.42)\end{array}$ & $\begin{array}{l}0.0756 \\
(3.49)\end{array}$ & $\begin{array}{l}0.0984 \\
(3.46)\end{array}$ & $\begin{array}{c}0.0476 \\
(0.39)\end{array}$ & $\begin{array}{c}0.1684 \\
(8.33)\end{array}$ \\
\hline Female & $\begin{array}{c}-0.1698 \\
(-3.15)\end{array}$ & $\begin{array}{c}-0.0151 \\
(-0.69)\end{array}$ & $\begin{array}{c}-0.1960 \\
(-8.59)\end{array}$ & $\begin{array}{c}-0.3518 \\
(-5.35)\end{array}$ & $\begin{array}{c}-0.1549 \\
(-9.65)\end{array}$ \\
\hline Sent down & $\begin{array}{l}0.0852 \\
(1.58)\end{array}$ & $\begin{array}{c}-0.0332 \\
(-1.16)\end{array}$ & $\begin{array}{c}-0.0326 \\
(-1.11)\end{array}$ & $\begin{array}{c}0.0246 \\
(0.24)\end{array}$ & $\begin{array}{c}0.0068 \\
(0.3)\end{array}$ \\
\hline $\begin{array}{l}\text { Employment } \\
\text { rate of city }\end{array}$ & $\begin{array}{c}-0.0012 \\
(-0.36)\end{array}$ & $\begin{array}{c}-0.0031 \\
(-1.96)\end{array}$ & $\begin{array}{c}-0.0046 \\
(-2.55)\end{array}$ & $\begin{array}{c}-0.0024 \\
(-0.45)\end{array}$ & $\begin{array}{r}-0.0027 \\
(-2.18)\end{array}$ \\
\hline $\begin{array}{l}\text { Average per } \\
\text { capita income } \\
10 \text { province } \\
\text { dummies }\end{array}$ & $\begin{array}{c}0.0001 \\
(4.75)\end{array}$ & $\begin{array}{l}0.0001 \\
(11.44)\end{array}$ & $\begin{array}{c}0.0001 \\
(8.88)\end{array}$ & $\begin{array}{c}0.0001 \\
(2.66)\end{array}$ & $\begin{array}{l}0.0001 \\
(10.37)\end{array}$ \\
\hline Constant & $\begin{array}{l}6.1247 \\
(7.61)\end{array}$ & $\begin{array}{l}7.4611 \\
(22.92)\end{array}$ & $\begin{array}{l}6.8474 \\
(25.90)\end{array}$ & $\begin{array}{l}7.9995 \\
(9.51)\end{array}$ & $\begin{array}{l}7.0957 \\
(41.03)\end{array}$ \\
\hline Adjusted R2 & 0.2648 & 0.2405 & 0.2398 & 0.1783 & 0.2666 \\
\hline $\begin{array}{l}\text { Number of } \\
\text { observations }\end{array}$ & 504 & 1968 & 2336 & 463 & 5497 \\
\hline
\end{tabular}




\section{Appendix}

Table A 1 Household income, wealth and house square meters per capita among various labor market categories 1995 and 2002. Yuan (as in 2002).

\begin{tabular}{|c|c|c|c|c|c|}
\hline & 1995 & & 2002 & & \multirow[t]{2}{*}{ Increase. Percentage } \\
\hline Household Disposable Income Per Capita & Mean value & Gini & Mean value & Gini & \\
\hline High rank & 8945 & 0.29 & 16185 & 0.2997 & 80.94 \\
\hline Middle rank & 7591 & 0.3199 & 12587 & 0.29 & 65.81 \\
\hline Low rank & 6030 & 0.3123 & 9621 & 0.2891 & 59.55 \\
\hline Self-employed and private owners & 5891 & 0.4469 & 8703 & 0.3531 & 47.73 \\
\hline Wage earners elsewhere & 6053 & 0.3381 & 10580 & 0.3164 & 74.79 \\
\hline Non-worker & 6596 & 0.3344 & 8433 & 0.3107 & 27.85 \\
\hline Total & 6301 & 0.332 & 10010 & 0.3169 & 58.86 \\
\hline \multicolumn{6}{|l|}{ Household Wealth Per Capita } \\
\hline High rank & 17243 & 0.5062 & 80589 & 0.4261 & 367.37 \\
\hline Middle rank & 16429 & 0.4996 & 55750 & 0.4214 & 239.33 \\
\hline Low rank & 12790 & 0.4962 & 43091 & 0.4496 & 236.91 \\
\hline Self-employed and private owners & 17329 & 0.5246 & 48772 & 0.5388 & 181.45 \\
\hline Wage earners elsewhere & 13251 & 0.5242 & 48229 & 0.4932 & 263.96 \\
\hline Non-worker & 16991 & 0.5921 & 40845 & 0.4743 & 140.39 \\
\hline Total & 13698 & 0.5181 & 46134 & 0.4751 & 236.79 \\
\hline \multicolumn{6}{|l|}{ Housing space. Square meters per capita } \\
\hline High rank & 17.49 & 0.2744 & 21.67 & 0.2474 & 23.90 \\
\hline Middle rank & 16.53 & 0.2664 & 19.83 & 0.2509 & 19.96 \\
\hline Low rank & 14.71 & 0.2645 & 15.64 & 0.2548 & 6.32 \\
\hline Self-employed and private owners & 15.62 & 0.2601 & 19.02 & 0.3089 & 21.77 \\
\hline Wage earners elsewhere & 14.75 & 0.2659 & 17.67 & 0.2708 & 19.80 \\
\hline Non-worker & 16.34 & 0.3044 & 16.55 & 0.264 & 1.29 \\
\hline Total & 15.27 & 0.2733 & 17.58 & 0.2698 & 15.13 \\
\hline
\end{tabular}

Source: Authors calculation from CHIP, urban survey.

Note: Data of 1995 have been adjusted with CPI

Household disposable income consists of the sum of household member's personal income, plus household (but not individual specific) incomes (most prominently imputed rent from housing). 
Table A2 Determinants of different labor market categories 1995 and 2002.

\begin{tabular}{|c|c|c|c|c|c|c|}
\hline & " High rank & Middle rank & Low rank & $\begin{array}{l}\text { Self employed or } \\
\text { private owner }\end{array}$ & $\begin{array}{l}\begin{array}{l}\text { Else wage } \\
\text { earners }\end{array} \\
\end{array}$ & $\begin{array}{l}\text { Non } \\
\text { worker }\end{array}$ \\
\hline & $\begin{array}{l}\text { Coefficient } \\
\text { and z-value }\end{array}$ & $\begin{array}{l}\text { Coefficient } \\
\text { and z-value }\end{array}$ & $\begin{array}{l}\text { Coefficient } \\
\text { and z-value }\end{array}$ & $\begin{array}{l}\text { Coefficient and } \\
\text { z-value }\end{array}$ & $\begin{array}{l}\text { Coefficient } \\
\text { and z-value }\end{array}$ & \\
\hline \multicolumn{7}{|l|}{1995} \\
\hline Education year & $\begin{array}{r}0.0108 \\
(21.48)\end{array}$ & $\begin{array}{r}0.0305 \\
(34.81)\end{array}$ & $\begin{array}{l}-0.0251 \\
(-19.24)\end{array}$ & $\begin{array}{r}-0.0011 \\
(-3.65)\end{array}$ & $\begin{array}{r}-0.0096 \\
(-7.43)\end{array}$ & $\begin{array}{r}-0.0055 \\
(10.13)\end{array}$ \\
\hline Age & $\begin{array}{r}0.0037 \\
(2.30)\end{array}$ & $\begin{array}{r}0.0293 \\
(11.67)\end{array}$ & $\begin{array}{r}0.0188 \\
(7.69)\end{array}$ & $\begin{array}{r}0.0029 \\
(4.38)\end{array}$ & $\begin{array}{l}-0.0365 \\
(-16.49)\end{array}$ & $\begin{array}{l}-0.0182 \\
(-18.65)\end{array}$ \\
\hline Age square & $\begin{array}{r}0.00001 \\
(-0.37)\end{array}$ & $\begin{array}{r}-0.0003 \\
(-9.41)\end{array}$ & $\begin{array}{r}-0.0003 \\
(-8.54)\end{array}$ & $\begin{array}{r}-0.00004 \\
(-4.46)\end{array}$ & $\begin{array}{r}0.0003 \\
(11.53)\end{array}$ & $\begin{array}{r}0.0002 \\
(20.24)\end{array}$ \\
\hline Party member & $\begin{array}{r}0.0313 \\
(7.66)\end{array}$ & $\begin{array}{r}0.1051 \\
(13.56)\end{array}$ & $\begin{array}{r}-0.0630 \\
(-6.33)\end{array}$ & $\begin{array}{r}-0.0080 \\
(-5.36)\end{array}$ & $\begin{array}{r}-0.0359 \\
(-3.62)\end{array}$ & $\begin{array}{r}-0.0296 \\
(-9.05)\end{array}$ \\
\hline $\begin{array}{l}\text { Employment rate of } \\
\text { the residential city }\end{array}$ & $\begin{array}{r}-0.0009 \\
(-2.33)\end{array}$ & $\begin{array}{r}0.0020 \\
(3.11)\end{array}$ & $\begin{array}{r}0.000001 \\
(0.00)\end{array}$ & $\begin{array}{r}-0.0007 \\
(-3.16)\end{array}$ & $\begin{array}{r}0.0016 \\
(1.82)\end{array}$ & $\begin{array}{r}-0.0020 \\
(-4.55)\end{array}$ \\
\hline $\begin{array}{l}\text { Average per capita } \\
\text { city income }\end{array}$ & $\begin{array}{r}0.00001 \\
(6.23)\end{array}$ & $\begin{array}{r}0.00001 \\
(1.68)\end{array}$ & $\begin{array}{r}-0.00002 \\
(-5.3)\end{array}$ & $\begin{array}{r}-0.000003 \\
(-3.46)\end{array}$ & $\begin{array}{r}-0.000002 \\
(-0.55)\end{array}$ & $\begin{array}{r}0.00001 \\
(5.35)\end{array}$ \\
\hline Sent down & $\begin{array}{r}-0.0104 \\
(-2.89)\end{array}$ & $\begin{array}{r}-0.0051 \\
(-0.76)\end{array}$ & $\begin{array}{r}0.0062 \\
(0.59)\end{array}$ & $\begin{array}{r}-0.0077 \\
(-5.21)\end{array}$ & $\begin{array}{r}0.0248 \\
(2.36)\end{array}$ & $\begin{array}{r}-0.0079 \\
(-1.42)\end{array}$ \\
\hline Minority & $\begin{array}{r}-0.0106 \\
(-1.54)\end{array}$ & $\begin{array}{r}0.0065 \\
(0.46)\end{array}$ & $\begin{array}{r}0.0153 \\
(0.79)\end{array}$ & $\begin{array}{r}-0.0019 \\
(-0.52)\end{array}$ & $\begin{array}{r}-0.0104 \\
(-0.56)\end{array}$ & $\begin{array}{r}0.0010 \\
(0.12)\end{array}$ \\
\hline Male & $\begin{array}{r}0.0169 \\
(4.74)\end{array}$ & $\begin{array}{r}0.0004 \\
(0.08)\end{array}$ & $\begin{array}{r}0.0684 \\
(8.61)\end{array}$ & $\begin{array}{r}0.0038 \\
(1.82)\end{array}$ & $\begin{array}{r}-0.0587 \\
(8.13)\end{array}$ & $\begin{array}{l}-0.0309 \\
(-12.05)\end{array}$ \\
\hline $\begin{array}{l}10 \text { province } \\
\text { dummies }\end{array}$ & & & & & & \\
\hline $\begin{array}{l}\text { Number of } \\
\text { observations } \\
\mathbf{2 0 0 2}\end{array}$ & 631 & 2394 & 5723 & 187 & 5437 & 802 \\
\hline Education year & $\begin{array}{r}0.0111 \\
(18.89)\end{array}$ & $\begin{array}{r}0.0318 \\
(34.14)\end{array}$ & $\begin{array}{r}-0.0113 \\
(-11.4)\end{array}$ & $\begin{array}{r}-0.0046 \\
(-9.7)\end{array}$ & $\begin{array}{r}-0.0018 \\
(-1.35)\end{array}$ & $\begin{array}{l}-0.0253 \\
(-24.98)\end{array}$ \\
\hline Age & $\begin{array}{r}0.0148 \\
(6.887)\end{array}$ & $\begin{array}{r}0.0359 \\
(13.62)\end{array}$ & $\begin{array}{r}0.0291 \\
(13.4)\end{array}$ & $\begin{array}{r}0.0081 \\
(6.87)\end{array}$ & $\begin{array}{r}0.0110 \\
(4.21)\end{array}$ & $\begin{array}{l}-0.0989 \\
(-75.98)\end{array}$ \\
\hline Age square & $\begin{array}{r}-0.0001 \\
(-6.15)\end{array}$ & $\begin{array}{l}-0.0004 \\
(-13.17)\end{array}$ & $\begin{array}{r}-0.0004 \\
(-14.6)\end{array}$ & $\begin{array}{r}-0.0001 \\
(-7.31)\end{array}$ & $\begin{array}{r}-0.0002 \\
(-5.18)\end{array}$ & $\begin{array}{r}0.0012 \\
(71.49)\end{array}$ \\
\hline Party member & $\begin{array}{r}0.0218 \\
(5.78)\end{array}$ & $\begin{array}{r}0.0798 \\
(11.49)\end{array}$ & $\begin{array}{r}-0.0170 \\
(-2.37)\end{array}$ & $\begin{array}{r}-0.0207 \\
(-9.05)\end{array}$ & $\begin{array}{r}0.0336 \\
(3.33)\end{array}$ & $\begin{array}{l}-0.0974 \\
(-13.14)\end{array}$ \\
\hline $\begin{array}{l}\text { Employment rate of } \\
\text { the residential city }\end{array}$ & $\begin{array}{r}0.0001 \\
(0.24)\end{array}$ & $\begin{array}{r}0.0027 \\
(7.09)\end{array}$ & $\begin{array}{r}0.0010 \\
(2.19)\end{array}$ & $\begin{array}{r}-0.00002 \\
(-0.11)\end{array}$ & $\begin{array}{r}0.0022 \\
(3.62)\end{array}$ & $\begin{array}{l}-0.0059 \\
(-12.37)\end{array}$ \\
\hline $\begin{array}{l}\text { Average per capita } \\
\text { city income }\end{array}$ & $\begin{array}{r}0.000002 \\
(2.26)\end{array}$ & $\begin{array}{r}0.00001 \\
(-4.07)\end{array}$ & $\begin{array}{r}0.00001 \\
(4.13)\end{array}$ & $\begin{array}{r}-0.0000045 \\
(-5.04)\end{array}$ & $\begin{array}{r}0.000004 \\
(1.68)\end{array}$ & $\begin{array}{r}-0.000003 \\
(-1.52)\end{array}$ \\
\hline Sent down & $\begin{array}{r}-0.0048 \\
(-1.53)\end{array}$ & $\begin{array}{r}-0.0082 \\
(-1.27)\end{array}$ & $\begin{array}{r}0.0309 \\
(3.48)\end{array}$ & $\begin{array}{r}-0.0069 \\
(-1.89)\end{array}$ & $\begin{array}{r}-0.0189 \\
(-1.76)\end{array}$ & $\begin{array}{r}0.0079 \\
(0.89)\end{array}$ \\
\hline Minority & $\begin{array}{r}-0.0035 \\
(-0.48)\end{array}$ & $\begin{array}{r}0.0044 \\
(0.34)\end{array}$ & $\begin{array}{r}-0.0295 \\
(-2.09)\end{array}$ & $\begin{array}{r}0.0391 \\
(3.45)\end{array}$ & $\begin{array}{r}0.0053 \\
(0.26)\end{array}$ & $\begin{array}{r}-0.0158 \\
(-1.03)\end{array}$ \\
\hline Male & $\begin{array}{r}0.0278 \\
(6.88)\end{array}$ & $\begin{array}{r}0.0362 \\
(6.33)\end{array}$ & $\begin{array}{r}0.0750 \\
(10.9)\end{array}$ & $\begin{array}{r}0.0185 \\
(5.14)\end{array}$ & $\begin{array}{r}-0.0200 \\
(-2.57)\end{array}$ & $\begin{array}{l}-0.1373 \\
(-27.19)\end{array}$ \\
\hline $\begin{array}{l}10 \text { province } \\
\text { dummies }\end{array}$ & & & & & & \\
\hline $\begin{array}{l}\text { Number of } \\
\text { observations }\end{array}$ & 504 & 1975 & 2347 & 468 & 5511 & 4264 \\
\hline
\end{tabular}

Note: the omitted category is low rank. 